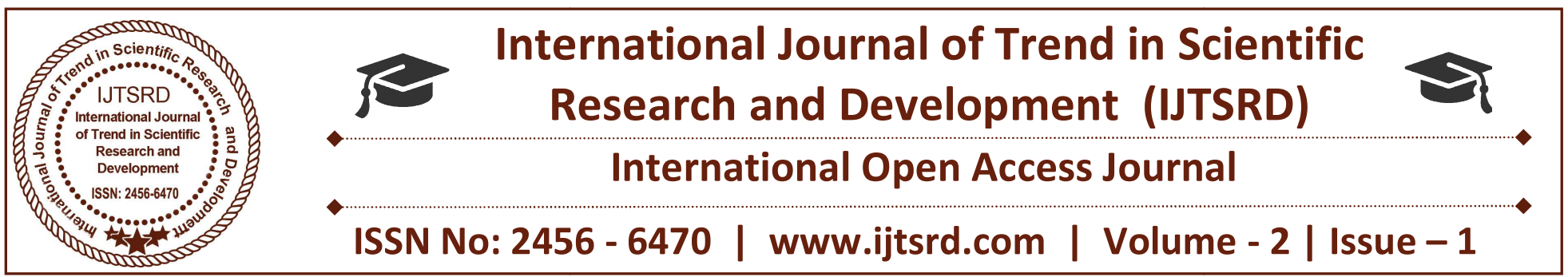

\title{
Socio - Economic Profile of the Women Consumers and their Opinion on Purchase of Products from Departmental Stores in Erode District
}

\author{
Dr.V.K.Sasikala \\ Assistant Professor, J. K. K. Nataraja College of Arts \& Science, \\ Komarapalayam, Namakkal, Tamil Nadu, India
}

\begin{abstract}
The departmental store enables the customers to purchase their entire requirement under one roof and hence the customers need not go to different shops for the purchase of products. This provides great convenience to the customers and also saves their time and labour. The present study focuses on the socio - economic profile of the female customers and to find out their opinion about quality of the product, service and price of the products while purchasing the products from the department stores.
\end{abstract}

Keywords: Requirement, Roof, Convenience, labour, Quality, Service

\section{Introduction}

Gone are the days were the consumer went in search of materials from shop to shop. Today, things are made available in one shop, one place. These days; consumer buying is not mere transfer of item from seller to buyer. Consumer wants buying to become a happy affair. They would like to see, touch and feel the commodities that they buy. Understanding this psychology for the consumer many organizations have come to make purchase of happy affair a department store is a retail establishment which specializes in satisfying a wide range of the consumer's personal and residential durable goods product needs; and at the same time offering the consumer a choice multiple merchandise lines, at variable price points, in all product categories.

\section{Statement of the problem}

In this study, an attempt has been made by the researcher to find the answers to the following questions.

What are the needs of the women consumers?

$>$ What are their opinions on quality of the product, service and price of the products while purchasing the products from the department stores?

$>$ How the departmental stores are to be modernized?

\section{Objectives of the Study}

The following are the objectives of the study.

1. To study the socio - economic profile of the female customers.

2. To find out the customers' opinion quality of the product, service and price of the products while purchasing the products from the department stores.

3. To offer suitable suggestions based on the findings of study.

\section{Statistical Tools}

The following tools of analysis were used for the study.

Simple percentage analysis

$>$ Chi-square analysis 


\section{Scope of the study}

The scope of present study has been restricted to Erode district in terms of customer satisfaction. The study has been undertaken on the basis of sample survey. The study mainly elicits views from consumers about price, quality, package, door delivery, availability, convenience, quantity, and after sales service.

\section{Limitations of the study}

The study suffers from the following limitation:

$>$ The study area is restricted only to Erode District.

> Sample size has been restricted to 600 sample due to time constrains.

$>$ At the time of completing the questionnaire, the researcher had faced some problems like unwillingness of the respondents and inability of the respondents in filling the questionnaire.

\section{Analysis and Interpretation}

Socio-economic profile of the Respondents

Table 1: Age of the Respondents

\begin{tabular}{|l|l|l|}
\hline Age & $\begin{array}{l}\text { No. } \\
\text { respondents }\end{array}$ & of \\
\hline below 20 years & 75 & 12.50 \\
\hline 20 to 30 years & 135 & 22.50 \\
\hline 30 to 40 years & 180 & 30.00 \\
\hline $\begin{array}{l}\text { Above } \\
\text { years } \\
\text { Total }\end{array}$ & 210 & 35.00 \\
\hline
\end{tabular}

\section{Sources: Survey data}

The above table 1 shows that $12.50 \%$ of the respondents with the age group of below 20 years, $22.50 \%$ of the respondents belongs to the age group of 20 to 30 years, $30.00 \%$ of the respondents belongs to the age group of 30 to 40 years, $35.00 \%$ of the respondents belong to the age group of above 40 years.

It is concluded from the above analysis that majority $(35 \%)$ of the respondents belong's to the age group of above 40 .
Table 2: Marital Status of the Respondents

\begin{tabular}{|c|c|c|}
\hline Marital status & $\begin{array}{l}\text { No. } \\
\text { respondents }\end{array}$ & Percentage \\
\hline Married & 420 & 70.00 \\
\hline Unmarried & 180 & 30.00 \\
\hline Total & 600 & 100.00 \\
\hline
\end{tabular}

Sources: Survey data

It is observed table 2 shows that $70.00 \%$ of the respondents married and remaining $30.00 \%$ of the respondents are unmarried.

It is concluded from the above analysis that majority $(70.00 \%)$ of the respondents are married.

\section{Table 3: Occupational Status of the Respondents}

\begin{tabular}{|l|l|l|}
\hline $\begin{array}{l}\text { Occupation } \\
\text { status }\end{array}$ & $\begin{array}{l}\text { No. } \\
\text { respondents }\end{array}$ & of \\
\hline House wives & 180 & 30.00 \\
\hline Farmer & 81 & 13.50 \\
\hline Business & 105 & 17.50 \\
\hline $\begin{array}{l}\text { Government } \\
\text { employee }\end{array}$ & 120 & 20.00 \\
\hline $\begin{array}{l}\text { Others } \\
\text { Total }\end{array}$ & 114 & 19.00 \\
\hline Source & $\mathbf{6 0 0}$ & $\mathbf{1 0 0 . 0 0}$ \\
\hline
\end{tabular}

\section{Source: Survey data}

The above table 3 shows that $30.00 \%$ of the respondents are House wives, $13.50 \%$ of the respondents are Farmer, $17.50 \%$ of the respondents are Business, $20.00 \%$ of the respondents are Government employee, $19.00 \%$ of the respondents are others.

It is concluded from the above analysis that majority $(30.00 \%)$ of the respondents are House wives. 
Chi-Square Analysis:

Table 4: Relationship between Age and Price of Product

\begin{tabular}{|l|l|l|l|}
\hline \multirow{2}{*}{ Age } & \multicolumn{2}{|l|}{$\begin{array}{l}\text { Level of satisfaction } \\
\text { Satisfaction }\end{array}$} & $\begin{array}{l}\text { Low } \\
\text { satisfaction }\end{array}$ \\
\hline $\begin{array}{l}\text { below } 20 \\
\text { years }\end{array}$ & 75 & 60 & 135 \\
\hline $\begin{array}{l}20 \text { to } 30 \\
\text { years }\end{array}$ & 135 & 45 & 180 \\
\hline $\begin{array}{l}30 \text { to } 40 \\
\text { years }\end{array}$ & 68 & 52 & 120 \\
\hline $\begin{array}{l}\text { Above } 40 \\
\text { years }\end{array}$ & 90 & 75 & 165 \\
\hline Total & $\mathbf{3 6 8}$ & $\mathbf{2 3 2}$ & $\mathbf{6 0 0}$ \\
\hline
\end{tabular}

Degree of freedom $=3$

Level of significance $=5 \%$

Calculated value $\quad=20.34$

Table value $\quad=7.814$

It is identified from the above table 4 that the calculated chi-square value is greater than the table value. So the framed null hypothesis has been rejected. Hence, it could be concluded that there is close relationship between Age and Price of product.

Table 5

Relationship between Age and Quality of Product

\begin{tabular}{|l|l|l|l|}
\hline \multirow{2}{*}{ Age } & \multicolumn{2}{|c|}{ Level of satisfaction } & Total \\
\cline { 2 - 4 } & Satisfied & $\begin{array}{l}\text { Low } \\
\text { satisfied }\end{array}$ & \\
\hline below 20 & 83 & 52 & 135 \\
\hline $\mathbf{2 0}$ to 30 & 105 & 75 & 180 \\
\hline $\mathbf{3 0}$ to 40 & 75 & 45 & 120 \\
\hline above 40 & 105 & 60 & 165 \\
\hline Total & $\mathbf{3 6 8}$ & $\mathbf{2 3 2}$ & $\mathbf{6 0 0}$ \\
\hline
\end{tabular}

Degree of freedom $=3$

Level of significance $=5 \%$

Calculated value $\quad=1.69$

Table value $\quad=7.814$

It is evident from the above table 5 that the calculated chi-square value is less than the table value. So the framed null hypothesis has been accepted. Hence, it could be concluded that there is no relationship between Age and Quality of product.
Table 6

Relationship between Age and Customer Service

\begin{tabular}{|l|l|l|l|}
\hline \multirow{2}{*}{ Age } & Level of satisfaction & Total \\
\cline { 2 - 4 } & Satisfied & $\begin{array}{l}\text { Low } \\
\text { satisfied }\end{array}$ & \\
\hline $\begin{array}{l}\text { below 20 } \\
\text { years }\end{array}$ & 90 & 45 & 135 \\
\hline $\begin{array}{l}\mathbf{2 0} \text { to } \mathbf{3 0} \\
\text { years }\end{array}$ & 113 & 68 & 180 \\
\hline $\begin{array}{l}\mathbf{3 0} \text { to } 40 \\
\text { years }\end{array}$ & 68 & 52 & 120 \\
\hline $\begin{array}{l}\text { About } \mathbf{4 0} \\
\text { years } \\
\text { Total }\end{array}$ & 98 & 67 & 165 \\
\hline
\end{tabular}

Degree of freedom $=3$

Level of significance $=5 \%$

Calculated value $\quad=3.09$

Table value $\quad=7.814$

It is observed from the above table 6 that the calculated chi-squire value is less than the table value. So the framed null hypothesis has been accepted. Hence, it could be concluded that there is no relationship between Age and Customer service.

\section{FINDINGS, SUGGESTIONS CONCLUSION}

AND

\section{Findings of the study:}

Female customers' opinion about the quality, service, price in departmental stores:

$>$ A majority of $70 \%$ of the sample respondents were married.

Majority of $35 \%$ of the sample respondents were to the age group of above 40 years.

$>$ A higher proportion of $30 \%$ of the respondents were in house wives.

There is close relationship between Age and Price of product.

$>$ There is no relationship between Age and Quality of product.

$>$ There is no relationship between Age and Customer service.

\section{SUGGESTIONS:}

The following are the suggestions based on the findings of the study. 
Attractive and effective advertisement through various media should be repeatedly given in order to capture the attention of potential customers.

$>$ Customers feel that more branches should be opened in many places especially nearest to their residence.

$>$ More price discount is to be given

$>$ The quality of the product must be maintained

$>$ The service is to be accelerated and maintained

\section{CONCLUSION:}

A departmental store is a large retail trading organization. The main aim of every departmental store is to provide and fulfill all requirements of their customers at one place along with comforts and facilities which a small scale retailer cannot provide. The departmental store is usually located in the central area of a large city. It serves maximum number of people. It offers wide variety customers. The motto of every departmental store is to provide high quality goods and render professional services to their customers. They spend heavily on sales promotion. It gives discounts, special seasonal offers, gift schemes, festival offers, etc.

\section{REFERENCES:}

1. Kothari, C.R: Research Methodology, New Age International PVT Limited, Publisher, New Delhi.

2. Gilbert A, Churchill, Jr., Marketing Research Methodological Foundations, USA, The Dryden Press, Fifth Edition, 1991.

3. D. Aaker, V.Kumar, and G. Day - Marketing Research, Singapore, John Wiley \& Sone (ASIA) Pte Ltd, Seventh Edition, 2003.

4. Kotler Philip, Principles of Marketing, Sultan Chand and Company Ltd., New Delhi, 2002.

5. Gupta .S.P: Statistical Methods, Sultan Chand @ sons, New Delhi.

6. Gunther Barth, "The Department Stores", in City people: The Rise of Moderns City Culture in Nineteenth-Century America. ( Oxford University Press, 1980) pp 110-47.

7. Ghosh, P., (2010), "Customer Expectations of Stores Attributes: A Study of Organized Retail Outlets in India", Journal of Retail \& Leisure Property, 9(1): pp.75-87. 